\title{
Evaluating the Impact of Microfinance for Women in Albania
}

\author{
Oltiana Muharremi ${ }^{1 *}$, Filloreta Madani ${ }^{1} \&$ Erald Pelari ${ }^{1}$ \\ ${ }^{1}$ Faculty of Economics, Department of Finance, University of Vlora "Ismail Qemali", Vlorë, Albania \\ *Oltiana Muharremi, E-mail: olta.muharremi@gmail.com
}

Received: September 13, 2016 Accepted: October 10, 2016 Online Published: October 20, 2016

doi:10.22158/jbtp.v4n2p233 URL: http://dx.doi.org/10.22158/jbtp.v4n2p233

\begin{abstract}
Microfinance is defined as any activity involving the offering of financial services such as loans, savings and insurance to individuals with low income. Creating social value includes reducing poverty and having a better impact to improve living conditions through capital for micro-enterprises; insurance and savings deposits for reducing risk and boosting consumption. Worldwide microfinance actors promote access to basic financial services by developing new tools, a variety of products and the adoption of an integrated banking access.

Initially, microfinance was largely gender neutral: it sought to provide credit to the poor who had no assets to pledge as collateral. It quickly emerged, however, that women invested their business profits in ways that would have a longer-lasting impact on their families and communities. Consequently women became fundamental to the success of the microfinance model as a poverty alleviation tool. The purpose of this article is to examine the impact of microfinance loans in improving the lives of women borrowers, as well as in strengthening their social influence and the microcredit impact in promoting savings. This study is based on an empirical investigation of 384 structured questionnaires and surveys directed at microfinance institutions and their clients in the regions of Vlore and Fier, Albania.
\end{abstract}

\section{Keywords}

microfinance, woman, empowerment, saving, income

\section{Introduction}

When the micro finance institution Grameen Bank and its founder Muhammad Yunus were awarded the Nobel Peace Prize in 2006: "for their efforts to create economic and social development from below", which ultimately would enhance democracy and human rights, it sent a signal to the world that microfinance had an important role, perhaps the most important one, as an instrument in combating poverty. Several recent randomized evaluations in different countries and contexts have found that granting communities access to microcredit has positive impacts on investment in self-employed activities, but no significant impact on overall consumption —or on overall income, when that is measured (Attanasio et al., 2011; Augsburg et al., 2013; Banerjee et al., 2013; Angelucci, Karlan, \& Zinman, 2013; Tarozzi, Desai, \& Johnson, 2013). A plausible interpretation of these findings is that the small businesses that the households gaining access to microcredit invest in have low marginal product of capital.

The initial motives behind the microfinance movement were social motives such as poverty reduction and improvement of living standards for the marginalized and excluded from traditional banking services. In many countries where microcredit was applied, it provided an opportunity to alleviate poverty, paid for itself and proved profitable in the many cases for the financial institutions that offer it; thus had a positive effect for individuals or groups who received its services. This potential, perhaps 
more than anything, is the triggering factor for the emergence and development of micro-credit on the world stage.

According to the World Bank, about $12.4 \%$ of the population in Albania, namely more than 275,000 residents live in poverty. But there are major differences between urban poverty and rural poverty. In rural areas, poverty ratio is $50 \%$ due to the lack of infrastructure, employment and the reduction of remittances and the impact it has on agriculture investments, livestock and other sectors associated with them.

\section{Literature Review}

Grameen Bank founded by Yunus, has shown throughout its existence a great interest in women and the big social change women have when they become members of the bank. There are a number of studies and empirical analyses that prove the above statement. It is generally assumed that microfinance positively impacts on women's livelihood in increasing their income. It helps women to better perform their reproductive role as brokers of the health, nutritional, and educational status of other household members. By increasing women's employment in micro enterprises and improving the productivity of women's income generating activities; and enhancing their self-confidence and self-esteem, and status within the family as independent producers and providers of valuable cash resources to the household economy (ILO, 1998). Many evaluations of MFIs have shown that microfinance services have a positive impact on women (Rai \& Ravi, 2011; Khandker, 2005; Lakwo, 2006; MkNelly \& Dunford, 1999; Morduch, 1998; Pitt \& Khandker, 1998; Pitt et al., 2006; Pitt et al., 2003). Empowering Women through Microfinance: Evidence from Tanzania found that credit programs had significant effects on eight different dimensions of women's empowerment. They found that women's access to credit was a significant determinant of the magnitude of economic contributions reported by women; of the likelihood of an increase in asset holdings in their own names; of an increase in their exercise of purchasing power; of their political and legal awareness as well as of the value of the composite empowerment index (Kabeer, 2001a).

Cheston and Kuhn, in their 2002 publication discuss the "evidence of improving conditions of women" and "the role that microcredit plays for this", referring frequently to specific cases of women in their research studies in Ghana, where women and girls were not taken into consideration and not listened to, but thanks to microfinance programs, they are now considered as human beings. According to their study, the ability for women to transform their lives for the better through financial services depends on various factors. These factors are associated with the individual and their skills; others depend on the environment and their status within a member group. Although microcredit is not successful in all cases, in most microfinance programs have a major impact on improving the living conditions of women.

Empowerment through microfinance is identified and measured in various dimensions: impact on decision-making, on self-confidence of women, on their status at home, on family relationships and the incidence of domestic violence, on their involvement in the community, on their political empowerment and rights (Cheston \& Kuhn, 2002). Although it is difficult to measure the exact impact of access to microcredit on different dimensions - such as impact on decision-making and on self-confidence - studies have shown that MFIs indeed have a positive effect on each of these different dimensions of women's empowerment.

An additional service that MFIs offer to women along with providing and lending loans is education regarding hygiene and health. In many poor countries MFIs offer learning for the illiterate or professional formation, which in turn contributes into their human development. This has meant that 
women have more respect and self-confidence, and an increase of their participation in family and community decision making. Littlefield, Morduch and Hashemi state that access to MFIs can empower women to become more confident, safer and more determined, and participate in family and community decisions and be better prepared to cope gender disparities (2003, p. 4). However, they also argue that the mere fact that women are clients of MFIs does not mean these social changes will automatically be enforced. Women's empowerment project in Nepal has shown that 68\% of women have had a greater role in family programming, child marriage, the sale of family property and sending the children to school. World Education has shown that the combination between money and education makes women seek better and equal treatment for their daughters thus forming a closed cycle with a wider range.

Hulme and Mosley also hold this view, when they refer to the "naiveté trust each loan granted to a woman contributes to strengthening the economic and social position of women" (1996, p. 128). However, with careful planning the position of women in the family and in the community can be improved. Mosedale says women need empowerment because they are limited by the "norms, beliefs, habits and values that societies distinguish between women and men" (2003, p. 2). Also it says that empowerment refers to "the process by which those who were denied the opportunity to make strategic choices for life, can regain a skill like that", where strategic choices are "critical for people to live the life they want; such as choice of life, to marry, whether to have children, etc.” (Kabeer, 1999, p. 437). Therefore MFIs cannot enforce women directly, but can help them through training and awareness to challenge existing norms, cultures and values which put them at a disadvantage in relation to men, and to help them have greater control over their resources and their way of life. Other studies have shown that decision-making skills have increased greatly especially the management of funds for home spending and business activities. Thanks to microcredit programs, women have had the opportunity to have organizational roles for social change and participate in community meetings. All this has been possible after they are put in a position to contribute financially to the needs of the community. Many studies during the 1990s and 2000s confirm the positive effects of microcredit as a social inclusion instrument and cultural economical enlargement of women in poor countries.

\section{Poverty in Albania}

Poverty in Albania has a multidimensional character. It is not identified only by the unemployed or families living in economic poverty, but it also represents categories of people which are excluded from basic rights to have a house, adequate food, heating and clothing in winter, work in accordance with physical skills and education level, schools close to home and the opportunity to follow it, access to health services, protection from theft and violence, rights and free speech to demand their civil liberties. In Albania poverty in the new century mainly has affected the young generation. It dominates on the rural population, families with many members and children, the unemployed and people with lower education. The poorest group in Albania is the younger generation. More than 55\% of the poor population is under 25 years, while this age group comprises only $33 \%$ of the total population. This is contrary to the popular perception that the groups most affected by poverty are seniors. On the contrary, only $10 \%$ of the poor population is 60 years or older. The unemployment rate increased from $12.5 \%$ in 2008 to $18 \%$ in 2014 . The lack of jobs is more pronounced on vulnerable groups such as the youth and women. Continuous output gap and tensions in the labor market are reflected in the downward trend of the rate of participation in the workforce. 
According to the joint report from the World Bank and INSTAT "Albania, the trend of poverty (Note 1)" poverty is not just a rural issue. There has been a shift of poverty from rural to urban areas, where the latter has experienced a large increase in poverty as a result of more focused effort towards rural development, while the continuous demographic movement from rural areas to urban areas has subsequently increased people living in poverty in urban areas. The poverty rate in rural areas increased from $15.0 \%$ in 2008 to $15.5 \%$ in 2012 , while urban poverty increased from $10.2 \%$ to $13.3 \%$.

\section{Women Empowerment in Albania}

Regarding the gender distribution of the respondents from the survey 55.7\% were females and $44.3 \%$ males. Throughout the world the biggest number and beneficiaries of microfinance programs are women, but the same thing cannot be said for Albania, because the respondents in this study were selected randomly without any gender bias. Empowerment occurs when individuals and organized groups are able to imagine the world in different ways and to realize this vision change the government structure and its relationship towards them, which keeps them in poverty (Note 2). Empowerment is a multi-dimensional process, non-linear that evolves through change along four different ways-material, perceptual, cognitive and liaison. Analyzing empowerment from this perspective makes the processes of change look more structured (Note 3 ):

$>\quad$ The material way-It includes changes in access to and control over material resources, changes in revenues, ownership of assets, the fulfillment of basic needs and the acquisition of skills.

$>$ The perceptual way-It includes changes in self-perception of women. Self-respect, self-confidence, visions and plans for the future, as well as changes in how women are perceived by others (visibility, respect, recognition, evaluation).

$>$ The cognitive way-Changes in the level of knowledge, skills and awareness of a wider environment.

$>\quad$ The liaison way - Changes related to social interaction (the decision-making process, contractual power, participation, self-reliance, organizational strength and mobility).

Access to microcredit can cause a number of changes. These changes have the potential to empower women in different ways. For example microcredit increases income (the material way) through business expansion. This can lead to increased self-reliance (the liaison way) and increased confidence (the perceptual way). The empowerment of women could be of social, economic or political character. In Albania gender inequality still exists, which is more sensitive in rural areas. In recent years Albania has improved the status of women and promoted gender equality. However, the country still faces many challenges in terms of fully displaying and utilizing the women's potential in the labor market and economy, increasing participation in decision-making and eradicating the widespread violence against women, particularly in the family realm. In addition, the country still needs to strengthen its legislative and institutional framework pertaining to gender equality and non-discrimination, improve monitoring and accountability of public offices towards women as well as ensure gender mainstreaming in public policies (Note 4). In a specific part of the questionnaire a section is dedicated to women to test the impact microcredit lending has in empowering them. Empowerment happens due to a variety of other causes that are linked to the context where microcredit landing is approved, the location, the country's economic situation and other factors as well. Regarding aspects for strengthening the liaison way and its perception, the importance of socio-cultural background needs to stand out. When asked whether the microcredit loan has empowered you, 67\% of them answered "Yes" and $23 \%$ of them answered "No". A significant portion of borrowers are women, perhaps because it 
may be the only person that provides more income for the family and needs to sign jointly to obtain a loan as a person who meets the conditions required by the MFIs.

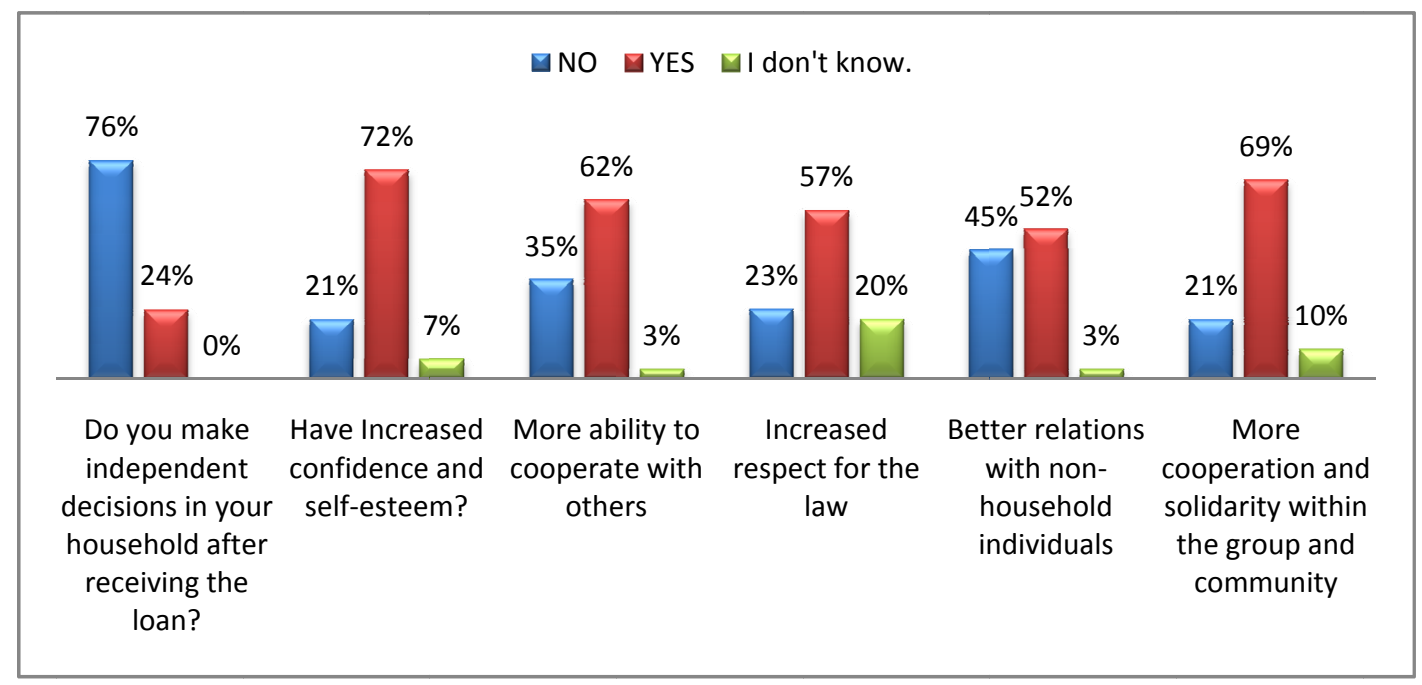

Figure 1. The Impact of Microcredit in Empowering Women

Source: The survey data. Author's work.

In this section the observation is focused on how microcredit lending for females has affected their social relations between them and the community. Based on the chart above from the questions given in the survey one can conclude:

1) The question: "Do you make independent decisions in your household after receiving the loan?" $76 \%$ answered "No", 24\% answered "Yes", and 0\% answered "I don't know". Gender roles and relationships strongly influence the strengthening processes within the family level. On household decision-making, from the survey one can easily notice that in strong traditional families, male dominance prevents women to gain control in other aspects of family life besides that of financial expenses. The progress of women in this field also depends on family income and financial contributions from their husbands. Moreover, the traditional role of women burdens them with a range of responsibilities and tasks in their homes, which makes it difficult for them to develop any initiatives for empowerment.

2) The question: "Have Increased confidence and self-esteem?"; The self-perception of customers is difficult to understand because of their very personal subjective and often vague nature. Involvement in microcredit programs improves confidence and self-esteem as the majority of respondents positively answered the question. 72\% of them answered "Yes", 21\% answered "No" and 7\% say "I do not know". Microcredit is a starting point for women to improve self-esteem by providing them with the opportunity to be proud for their financial contribution to the family (provided that credit leads to increased income), and seeing that a number of women in the survey were business owners, microcredit has affected the growth and development of businesses run by them. In this way, microcredit supports the internal strengthening of the psychological processes for the female customers.

3) "More ability to cooperate with others": Microcredit has increased the ability for women to cooperate more with others, to create social links with them, to have more empowerment associated with participation in groups as 62\% answered "Yes", 35\% answered "No" and 3\% "I do not know". 
4) The question after receiving the loan: "Do you have increased respect for the law" $-57 \%$ of them answered "Yes", 23\% answered "No" and 20\% "I do not know". Mainly the implementation of the rules has to do with the regular payment of loan installments, the observance of the required standards relating to products sold to customers, and the ethical behavior towards customers.

5) "Better relations with non-household individuals"-In some clients microcredit has led to increased income and trust as well as greater respect from other people because of personal wealth growth. This has been one of the motives that relations with non-household individuals has improved such as: clients or suppliers. After having been approved a microcredit the individuals that were surveyed gave the following answers to this question: $52 \%$ said "Yes", $45 \%$ answered "No" and $3 \%$ of the respondents answered "I do not know".

6) The question: "More cooperation and solidarity within the group and community" - after receiving the loan $69 \%$ of female respondents answered "Yes", 21\% answered "No" and 10\% said "I do not know".

$62 \%$ of women surveyed have increased savings and profitability after using microcredit loans. Accumulated money can also safeguard against expected or unexpected spikes in household expenses due to childbirth, educational fees, house repairs, life-cycle celebrations, or widowhood. Savings may also cushion family risks due to illness, theft, or job loss or structural risks due to war, floods, or fire. Finally, savings allow people to take advantage of unexpected investment opportunities. As stored resources, savings are useful for a wide range of purposes.

When asked about the reasons for which they intend to use future earnings, they gave the following answers: $25 \%$ of them listed "to invest in personal activity" as the main usage of their savings; about $17 \%$ the main reason for saving was "more security in the future", $15 \%$ did so "to improve the economic situation", $14 \%$ would use the savings to "provide income for the education of children", $10 \%$ "for the future of their children". From the questionnaire we notice that MFI clients who own a business save to invest more in the future for their enterprise, while clients for consumer loans are those that save less and mainly buy basic products in the future. This is clear evidence that microcredit directs customers towards long term financial planning, making them save for future investments and for meeting other needs such as education, a better future for the children surpassing the basic needs for a normal livelihood.

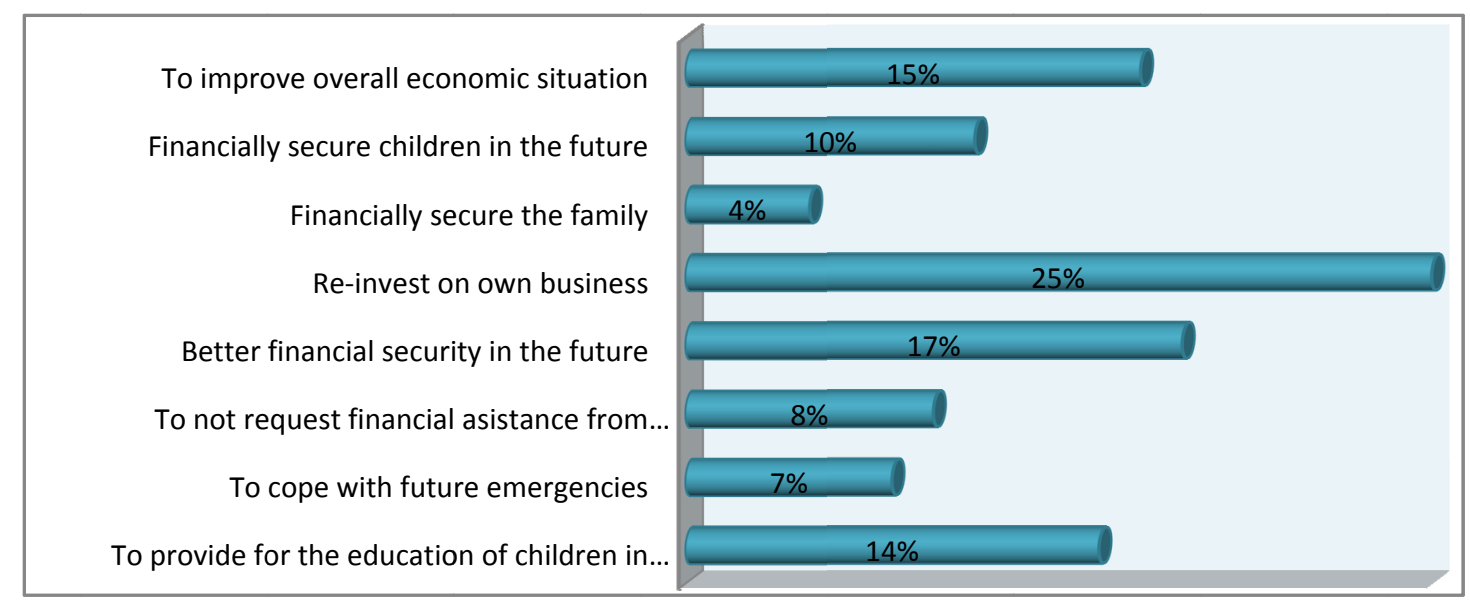

Figure 2. Reasons for the Use of Savings in the Future

Source: The survey data. Author's work. 
First Hypothesis (H1): There is a connection between increased household income through microfinance and savings for individuals

In order to verify this hypothesis we will take a look at the relationship between two variables, the increase in revenues and the impact on savings. Individuals are divided into two groups based on gender, and to see if there are differences with the ability to save between men and women. Microfinance is mentioned in many scientific articles as an instrument that contributes to an increase in savings for its beneficiaries, mainly women. We will test this statement and try to verify whether it applies to Albania. Individuals apply for loans trying to change their economic situation. If they own a business, loans are used to invest, which presumably will be profitable in the future. After taking care of operating costs, they try to save money in order to reinvest it in the business, or hope that future savings will improve their financial status. There is a positive statistical link between increased level of household income and savings growth (Note 5).

The loan can be used for consumption, which has no impact on revenue growth for borrowers. Individuals struggle to save for the future in order to improve their financial status and standard of living. We perform the Pearson correlation test in order to find the relationship between income growth and increased savings. Null hypothesis (H0): There is no relationship between income growth and rising household savings. In contrast, the alternative hypothesis H1: There is a link between the growth of household income and savings growth. Results are shown in Table1 the women category.

Table 1. The Correlation between Income Growth and Savings

\begin{tabular}{llll}
\hline & Correlations & Savings W & Increased Income W \\
\hline Pearson Correlation & Savings W & 1.000 & .255 \\
& Increased Income W & .255 & 1.000 \\
Sig. (1-tailed) & Savings W &. & .000 \\
& Increased Income W & .000 &. \\
$\mathrm{~N}$ & Savings W & 213 & 213 \\
& Increased Income W & 213 & 213 \\
\hline
\end{tabular}

We see Pearson's correlation coefficient of 0.255. Correlation is significant at the 0.01 level. The level of significance was 0.000 and to be credible it must be less than 0.05 . Thus hypothesis H0 is rejected and the alternative hypothesis is accepted recognizing that there is a connection through income growth and consumption growth for women.

Table 2. A Summary of the Model, the Connection between Income and Savings for Women

\begin{tabular}{|c|c|c|c|c|c|}
\hline \multicolumn{6}{|c|}{ Model Summary } \\
\hline \multirow[b]{3}{*}{ Model } & \multirow[b]{3}{*}{$\mathrm{R}$} & \multirow[b]{2}{*}{$\mathrm{R}$} & \multicolumn{3}{|c|}{ Change Statistics } \\
\hline & & & Adjusted & RStd. Error ofR & SquareF \\
\hline & & Square & Square & the Estimate Change & Change df1 df2 Change Durbin-Watson \\
\hline 1 & $.255^{\mathrm{a}}$ & .065 & .061 & .389 & 211.000 \\
\hline
\end{tabular}

a. Predictors: (Constant), Increased Income W;

b. Dependent Variable: Savings W.

The following Table shows the connection for the male category, we notice that Pearson correlation coefficient in this case is 0.398 . It is a higher value than in the case of category for women. The 
strength of the correlation can be described through Evans guide (1996) for the absolute value of the coefficient $r$ : very weak (0:00 to $0: 19)$, weak ( $0: 20$ to $0: 39)$, moderate $(0: 40$ to $0: 59)$, strong (0.60 to $0.79)$, and very strong ( 0.80 to 1.0$)$. Both estimated coefficients are positively correlated, but weak.

Table 3. The Correlation between Income Growth and Savings Growth for Men

\begin{tabular}{llll}
\hline & Correlations & Savings M & Increased Income M \\
\hline Pearson Correlation & Savings M & 1.000 & .398 \\
& Increased Income M & .398 & 1.000 \\
Sig. (1-tailed) & Savings M &. & .000 \\
& Increased Income M & .000 &. \\
$\mathrm{~N}$ & Savings M & 171 & 171 \\
& Increased Income M & 171 & 171 \\
\hline
\end{tabular}

Thus, these two variables are positively related, which means that when revenues grow, the ability of individuals to save increases, which positively impacts the financial situation of the family in the future. So, income growth and savings leads to economic empowerment of families and better employment opportunities in the future.

Table 4. A Summary of the Model, the Connection between Income and Savings for Men

\begin{tabular}{|c|c|c|c|c|c|c|c|}
\hline \multicolumn{8}{|c|}{ Model Summary } \\
\hline \multirow[b]{4}{*}{ ModelR } & & \multicolumn{5}{|c|}{ Change Statistics } & \multirow{4}{*}{$\begin{array}{l}\text { Sig. F } \\
\text { Change Durbin-Watson }\end{array}$} \\
\hline & & & Std. Error & $\mathrm{R}$ & & & \\
\hline & & Adjusted & Rof the & Square & $\mathrm{F}$ & & \\
\hline & $\mathrm{R} \mathrm{Squ}$ & reSquare & Estimate & Change & Change dfl & df 2 & \\
\hline $\begin{array}{ll}1 & .398^{\mathrm{a}}\end{array}$ & .158 & .154 & .454 & .158 & $31.827 \quad 1$ & 169 & 1.928 \\
\hline
\end{tabular}

a. Predictors: (Constant), Increased Income M;

b. Dependent Variable: Savings M.

We can conclude that the people, who were able to increase their income by taking loans from MFIs, were also able to increase their savings, even though in a small measure. This link is stronger for men than for women, contrary to the assertion being portrayed from empirical studies in poor countries, that women are more motivated to reach higher levels of savings when benefiting from microfinance services than men.

\section{Conclusions}

We evaluated the impact of microcredit in terms of savings growth through a statistical test. Namely to study this impact a hypothesis was built if a link existed between the increase of household incomes through microfinance and the savings of individuals. In order to confirm this hypothesis the Pearson correlation coefficient was used dividing the individuals that were surveyed into two categories based on gender. The results from the test were positive, but weak between the household income growth and savings. This coefficient was higher for men (0.398) than for women (0.255). This result does not go in line with studies achieved in developing countries where women are attributable to positive results, even in considerable amounts associated with increased household saving. The impact of microcredit on an individual level is estimated for women with questions about empowerment and the results show 
a substantial number of women positively regard microcredit lending. Gender roles and relationships strongly influence the processes of strengthening decision making attributes in the family level. On family decision-making, we have noticed that in traditionally strong families, men's authority prevents women to gain power over crucial aspects besides financial costs, only $24 \%$ of women responded positively. On the other hand self-assessment and self-confidence has increased for most of them.

\section{References}

Angelucci, M., Karlan, D., \& Zinman, J. (2013). Win Some Lose Some? Evidence from a Randomized Microcredit Program Placement Experiment by Compartamos Banco. Institute for the Study of Labor (IZA) IZA Discussion Papers 7439.

Attanasio, O., Augsburg, B., Ralph de Haas, Fitzsimons, E., \& Harmgart, H. (2011). Group lending or individual lending? Evidence from a randomised field experiment in Mongolia. Institute for Fiscal Studies IFS Working Papers W11/20.

Augsburg, B., De Haas, R., Harmgart, H., \& Meghir, C. (2012). Microfinance at the margin: Experimental evidence from Bosnia and Herzegovina. Working Paper.

Augsburg, B., De Haas, R., Harmgart, H., \& Meghir, C. (2013). Microfinance, Poverty and Education. National Bureau of Economic Research, Inc NBER Working Papers 18538.

Banerjee, A. (2013). Microcredit under the microscope: What have we learned in the past two decades, and what do we need to know? Annual Reviews of Economics, 5, 487-519. http://dx.doi.org/10.1146/annurev-economics-082912-110220

Banerjee, A., Duflo, E., Glennerster, R., \& Kinnan, C. (2013). The miracle of microfinance? Evidence from a randomized evaluation. MIT Department of Economics.

Caroll, C., \& Weil, D. (1994). Saving and growth, a reinterpretation. Carnegie-Rochester Conference Series on Public Policy 40, 133-192 North-Holland.

Chen, M., \& Mahmud, S. (1995). Assessing Change in Women's Lives. A Conceptual Framework, BRAC-ICDDR, B Joint Research Project Dhaka, Bangladesh Working Paper Number: 2.

Cheston, S., \& Kuhn, L. (2002). Empowering women through microfinance. In S. Daley-Harris, comp (Ed.), Pathways out of poverty: Innovations in microfinance for the poorest families (pp. 167-228) Bloomfield, CT, USA: Kumarian Press.

Evans, J. St. BT, \& Over, D. E. (1996). Rationality and reasoning. London, United Kingdom: Pyschology Press.

Eyben, R. et al. (2008). Conceptualising Empowerment and the Implications for Pro-Poor Growth. A Paper for the DAC Poverty Network.

Hashemi, S. M., Schuler, S. R., \& Riley, A. P. (1996). Rural credit programs and women's empowerment in Bangladesh. World Development, 24(4), 635-653. http://dx.doi.org/10.1016/0305-750X(95)00159-A

Hulme, D., \& Mosley, P. (1996). Finance against Poverty. Routledge, London.

ILO. (1998). Women in the informal sector and their access to microfinance (Inter-Parliamentary Union (IPU) Annual Conference, 2-11 April). Windhoek, Namibia.

INSTAT. SHQIPËRIA: TRENDI I VARFËRISË 2002-2005-2008-2012. (n.d.). Retrieved from http://www.instat.gov.al/media/288396/anketa_e_matjes_se_nivelit_te_jeteses_2012_rishikuar.p df

Kabeer, N. (1997). Women, wages and intra-household power relations in urban Bangladesh. Development and Change 28: 261-302. http://dx.doi.org/10.1111/1467-7660.00043 
Kabeer, N. (1998). Money Can't Buy Me Love? Re-evaluating Gender, Credit and Empowerment in Rural Bangldesh. IDS Discussion Paper 363.

Kabeer, N. (2001). Reflections on the measurement of women's empowerment. In Discussing Women's Empowerment-Theory and Practice. Sida Studies No. 3. Novum Grafiska AB: Stockholm.

Khandker, S. R. (2005). Microfinance and Poverty: Evidence Using Panel Data from Bangladesh. The World Bank Economic Review, 19(2), 263-286. http://dx.doi.org/10.1111/1467-7660.00043

Lakwo, A. (2006). Microfinance, rural livelihoods, and women's empowerment in Uganda (Doctoral Dissertation). Radboud University Nijmegen, Leiden, the Netherlands.

Littlefield, E., Morduch, J., \& Hashemi, S. (2003). Is microfinance an effective strategy to reach the Millennium Development Goals? CGAP focus note; no. 24. Washington, DC: World Bank. Retrieved from http://www.documents.worldbank.org/curated/en/982761468319745482/Is-miCro finance-an-effective-strategy-to-reach-the-Millennium-Development-Goals

MkNelly, B., \& Dunford, C. (1999). Impact of Credit with Education on Mothers and Their Young Children's Nutrition: CRECER Credit with Education Program in Bolivia. Davis, CA: Freedom from Hunger.

Morduch, J. (1998). Does Microfinance Really Help the Poor? New Evidence from Flagship Programs in Bangladesh. New York: New York University.

Morduch, J. (1999). The microfinance promise. Journal of Economic Literature, 37(4), 1569-1614. http://dx.doi.org/10.1257/jel.37.4.1569

Mosedale, S. (2005). Assessing women's empowerment: Towards a conceptual framework. Journal of International Development, 17, 243-257. http://dx.doi.org/10.1002/jid.1212

Mosley, P., \& Hulme, D. (1998). Microenterprise finance: Is there a conflict between growth and poverty alleviation? World $\quad$ Development, 26(5), http://dx.doi.org/10.1016/S0305-750X(98)00021-7

Mushumbusi, P. K., \& Kratzer, J. (2013). Empowering Women through Microfinance: Evidence from Tanzania. ACRN Journal of Entrepreneurship Perspectives, 2(1), 31-59.

Pitt, M. M., \& Khandker, S. R. (1998). The Impact of Group-Based Credit Programs on Poor Households in Bangladesh: Does the Gender of Participants Matter? Journal of Political Economy, 106(5), 958. http://dx.doi.org/10.1086/250037

Pitt, M. M., Khandker, S. R., \& Cartwright, J. (2006). Empowering Women with Micro Finance: Evidence from Bangladesh. Economic Development and Cultural Change, 54(4), 791-831. http://dx.doi.org/10.1086/503580

Pitt, M. M., Khandker, S. R., Chowdhury, O. H., \& Millimet, D. L. (2003). Credit Program for the Poor and the Health Status of Children in Rural Bangladesh. International Economic Review, 44(1), 958-996. http://dx.doi.org/10.1086/503580

Rai, A., \& Ravi, S. (2011). Do Spouses Make Claims? Empowerment and Microfinance in India. World Development, 39(6), 913-921. http://dx.doi.org/10.1016/j.worlddev.2009.10.019

Tarozzi, A., Desai. J., \& Johnson, K. (2013). On the Impact of Microcredit: Evidence from a Randomized Intervention in Rural Ethiopia. Barcelona Graduate School of Economics Working Papers 741.

\section{Notes}

Note 1. http://www.instat.gov.al/media/288396/anketa_e_matjes_se_nivelit_te_jeteses_2012_rishI kuar.pdf 
Note 2. Eyben, R. et al. (2008). Conceptualising Empowerment and the Implications for Pro-Poor Growth. A Paper for the DAC Poverty Network.

Note 3. Chen, M., \& Mahmud, S. (1995). Assessing Change in Women's Lives. A Conceptual Framework, ngladesh.

Note 4. http://www.al.undp.org/content/albania/en/home/operations/projects/poverty_reduction/genderequality-and-gender-based-violence-programme-.html

Note 5. Caroll, C., \& Weil, D. (1994). Saving and growth, a reinterpretation, Carnegie-Rochester Conference Series on Public Policy 40, 133-192 North-Holland (p. 153). 